\title{
PENGARUH INOVASI PRODUK DAN DESAIN RUMAH MAKAN TERHADAP KEPUASAN KONSUMEN STUDI KASUS PADA KEDAI OHAYO KOTA TARAKAN
}

\author{
THE EFFECT OF RESTAURANT INNOVATION AND DESIGN ON CUSTOMER \\ SATISFACTION CASE STUDY IN TAVERN OHAYO TARAKAN CITY
}

\author{
Hanifah Amelia Fauziati ${ }^{1)}$, Nurjannatul Hasanah ${ }^{2)}$ \\ (Universitas Borneo Tarakan)
}

\begin{abstract}
Abstrak: Penelitian ini bertujuan untuk mengetahui pengaruh Inovasi Produk dan Desain Rumah Makan Terhadap Kepuasan Konsumen Pada Kedai Ohayo Kota Tarakan. Penelitian ini menggunakan pendekatan kuantitatif dengan metode survei. Metode pengambilan sampel yang digunakan dalam penelitian ini adalah nonprobability sampling dengan teknik penentuan sampel menggunakan purposive sampling. Sampel dalam penelitian ini adalah masyarakat kota Tarakan yang mengkonsumsi produk secara langsung di kedai Ohayo Kota Tarakan. Jumlah responden sebanyak 190 Responden. Metode analisis menggunakan analisis regresi dengan bantuan program SPSS versi 16.0. Hasil penelitian ini menujukkan bahwa Inovasi produk dan Desain rumah makan berpengaruh positif dan signifikan terhadap Kepuasan Konsumen Pada Kedai Ohayo Kota Tarakan.
\end{abstract}

Kata Kunci : Desain Rumah Makan, Inovasi Produk, Kepuasan Knsumen

This study aims to determine the effect of Product Innovation and Restaurant Design on Consumer Satisfaction at the Ohayo Tavern in Tarakan City. This study uses a quantitative approach with survey methods. The sampling method used in this study is nonprobability sampling with the technique of determining the sample using purposive sampling. The sample in this study is the people of Tarakan city who consume products directly in the Ohayo store in Tarakan City. The number of respondents is 190 respondents. The analytical method uses regression analysis with the help of SPSS version 16.0. The results of this study show that product innovation and restaurant design have a positive and significant effect on consumer satisfaction at the Ohayo shop in Tarakan City.

Keywords: Customer Satisfaction, Product Innovation, Restaurant Design, 


\section{LATAR BELAKANG}

Kompleksitas dunia bisnis dan dinamika lingkungan bisnis global yang semakin meningkat mengakibatkan persaingan dalam dunia bisnis semakin kompetitif. Dengan adanya persaingan yang semakin ketat, maka perusahan perusahan dihadapkan pada berbagai peluang dan ancaman baik yang berasal dari luar maupun dari dalam negeri. Maka dari itu setiap perusahaan dalam menghasilkan produknya dituntut untuk selalu mengerti dan memahami apa yang terjadi dipasar dan apa yang menjadi keinginan konsumen. Perusahaan yang pintar selalu berupaya untuk meminimalisasi kelemahan dan memaksimalkan kekuatan yang dimilikinya. Dengan demikian perusahaan dituntut untuk memilih dan menetapkan strategi yang dapat digunakan untuk menghadapi persaingan (Tomi, et al. 2014).

Perkembangan bisnis rumah makan adalah salah satu fenomena yang sangat menarik untuk disimak, terlebih dengan adanya globalisasi yang semakin membuka peluang pengusaha untuk dapat berbisnis global dan menjaring konsumen secara luas, Tapi untuk dapat menjaring konsumen secara luas maka setiap perusahaan diharuskan untuk dapat menciptakan kepuasan bagi konsumen (Sari, 2014) Kepuasan konsumen dapat dilakukan dengan melakukan inovasi produk (Sukarmen, 2013). Kotler (2007) menyatakan bahwa inovasi produk adalah gabungan dari berbagai macam proses yang saling mempengaruhi antara satu dengan yang lain. Jadi inovasi bukanlah konsep dari suatu ide baru, penemuan baru atau juga bukan merupakan suatu perkembangan dari suatu pasar yang baru saja, tetapi inovasi merupakan gambaran dari semua proses tersebut. Studi oleh Ryu dan Han (2010) menegaskan pentingnya inovasi produk sebagai faktor kunci mempengaruhi kepuasan konsumen. Semakin ketatnya persaingan yang terjadi apalagi yang berasal dari perusahaan yang sejenis, menuntut suatu perusahaan agar selalu bergerak lebih cepat untuk hal menarik perhatian konsumen.

Para pelaku bisnis dalam bidang makanan juga dituntut pula untuk dapat selalu menggunakan strategi bersaing seperti menciptakan diferensiasi yang unik sehingga menciptakan suatu rasa yang berbeda dari pesaing. Rahmawati (2008) mengungkapkan para pelaku bisnis harus menyiapkan strategi agar dapat menyenangkan hati dan membangun rasa antusias konsumen menjadi suatu experience dalam mengkonsumsi produk dan jasa, sehingga akan membuat mereka terkesan. Penciptaan suasana nyaman yang didukung dengan desain interior unik dan tersedianya berbagai fasilitas tambahan seperti hiburan dan wifi serta sejenisnya merupakan daya tarik khusus bagi para customer-nya yang pada akhirnya akan mempengaruhi kepuasan konsumen. Tema dan gaya desain sebuah rumah makan merupakan aspek pendukung yang mampu membedakan antara rumah makan satu dengan lainnya untuk menarik pengunjung. Desain adalah kerangka bentuk suatu bangunan (rumah, taman, dan sebagainya), 
motif bangunan, pola bangunan dan corak bangunan. Desain pada sebuah rumah makan adalah perwujudan imajinasi baik dari pemilik maupun arsitek sebagai perancangnya.

Konsumen akan lebih banyak menghabiskan waktu dan uang di tempat yang lingkungan layanannya memberikan perasaan senang. Sehingga, hal yang terpenting bagi rumah makan adalah faktor lingkungan, gaya arsitektur, tata letak rumah makan perabot dan material, faktor-faktor sosial, serta faktor suasana. (Sari, 2014). Sebagai salah satu provinsi baru di Indonesia, Kaliamantan Utara dan kota Tarakan tepatnya menjadi sebagai salah satu kota di Kalimanta Utara yang menjadi pusat perekonomian yang potensial bagi para pegusaha food service modern untuk berinvestasi dan mengembangkan usaha, karena kota Tarakan merupakan kota yang sangat strategis menjadi tempat persinggahan atau tempat berkumpul masyarakat yang memiliki gaya hidup modern dan sosialis. Berbagai rumah makan baru yang ada di Kota Tarakan memiliki tingkat persaingan dengan usaha yang sejenis sehingga Pemilik usaha dituntut untuk memiliki fasilitas dan pelayanan yang lebih unggul sesuai kebutuhan konsumen agar dapat mempertahan kan eksistensi nya. Pemilik usaha makanan perlu mengetahui faktor faktor yang mempengaruhi ke putusan pembelian sehingga dapat mem pengaruhi kepuasan konsumen, diantaranya inovasi produk dan desain rumah makan (tarakankota.go.id)

Kedai Ohayo merupakan salah satu rumah makan yang menyajikan makanan dan minuman yang berbeda dari rumah makan yang lainnya, produk yang diberikan oleh Kedai Ohayo yang ada di Kota Tarakan kepada konsumen memberikan menu makanan yang berbeda dengan menyajikan menumenu makanan khas Jepang sehinga konsumen yang ingin menikmati makanan khas Jepang dapat mengunjungi Kedai Ohayo.

Menu makanan dan minuman yang di berikan beragam, konsumen dapat memilih sesuai dengan selera konsumen, menu makanan khas Jepang yang disajikan seperti sushi, yakiniku, stemboat dan minuman seperti thai tea dan green tea. Selama berdiri ohayo telah melakukan inovasi pada produk sebagai diferensiasi dengan perusahaan sejenis (Hengky, 2017), namun apakah dengan inovasi tersebut kedai Ohayo dapat menarik konsumen lebih banyak lagi dan memberikan kepuasan bagi konsumen. Sementara dari hasil pengamatan peneliti terhadap konsumen Ohayo baik konsumen yang langsung dari Ohayo maupun komentarkomentar konsumen terhadap sosial media Instagram Ohayo mengungkapkan bahwa Kedai Ohayo masih jauh dari harapan dengan rumah makan yang bertemakan tentang Jepan. para konsumen mengungkapkan bahwa desain yang ada di Ohayo masih kurang, dalam segi makanan juga jauh dari harapan yang dibayangkan, begitupula dengan minuman yang disediakan tidak sesuai dengan yang harapan konsumen.

\section{RUMUSAN MASALAH}

Berdasarkan latar belakang yang dikemukakan, penulis merasa 
tertarik untuk perlu meneliti lebih jauh tentang "Pengaruh inovasi produk dan desain Rumah makan terhadap kepuasan konsumen (studi kasus pada kedai Ohayo kota Tarakan).".

\section{TUJUAN PENELITIAN}

Sesuai dengan permaslahan yang telah dirumuskan, tujuan penelitian adalah sebagai berikut :

1. Untuk mengetahui Pengaruh inovasi produk terhadap kepuasan konsumen.

2. Untuk mengetahui Pengaruh desain Rumah makan terhadap kepuasan konsumen.

\section{TINJAUAN PUSTAKA}

Yang menjadi landasan teori dalam penelitian ini yang juga kemudian akan menjadi definisi konsep dan definisi operasional adalah inovasi produk menurut Kotler (2007) menyatakan bahwa inovasi produk adalah gabungan dari berbagai macam proses yang saling mempengaruhi antara yang satu dengan yang lain. Untuk mengukur Inovasi Produk digunakan 6 instrumen yang dikembangkan kotler (2007) berdasarkan instrumen yang digunakan dalam penelitian menggunakan 12 item pertayaan yang dikembangkan oleh Intan Firdaus (2016) terlampir pada kuesioner penelitian indikator inovasi produk sebagai berikut :

1. Produk baru bagi dunia

2. Lini produk baru

3. Tambahan pada lini produk yang telah ada

4. Perbaikan dan revisi yang telah ada
5. Penetuan kembali

6. Pengurangan biaya

Desain Rumah Makan adalah

Tema dan gaya desain sebuah restoran merupakan aspek pendukung yang mampu membedakan antara restoran satu dengan lainnya untuk menarik pengunjung (Lisa sekar Sari 2014). Unuk mengukur desain rumah makan digunakan 6 instrumen yang merupakan pengembangan dari instrumen Yuksel dan Yuksel (2002) indikator desain rumah makan adalah

1. Faktor lingkungan

2. Gaya arsitektur

3. Tata letak Rumah Makan

4. Perabot/ Properti

5. Faktor-faktor social

6. Faktor suasana

Kotler dan Keller (2009), mengemukakan bahwa Kepuasan adalah perasaan senang atau kecewa seseorang yang muncul setelah membandingkan kinerja hasil produk yang dipikirkan terhadap kinerja atau hasil yang diharapkan. Jika kinerja berada di bawah harapan, pelanggan tidak puas. Dan jika kinerja memenuhi harapan, pelanggan puas. Jika kinerja melebihi harapan, pelanggan amat puas atau senang. Untuk mengukur kepuasan konsumen digunakan instrumen yang merupakan pengembangan dari instrumen Stanton, William J. (1987) berdasarkan instrumen yang digunakan dalam penelitian menggunakan 12 item pertanyaan yang dikembangkan oleh Kemas M Reza (2012) terlampir pada lembar kuesioner.

Adapun indikator penelitian sebagai berkut:

1. Product 
2. Price

3. Place

4. Promotion

5. People

6. Physical evidence

7. Process

Adapun sebagai acuan dalam penelitian ini adalah yang dilakukan oleh Veri Agus Tomi (2014), Putu Sukarman (2013) Novarika Ariyanti (2015) Timoticin Kwanda (2003) Dalam acuan ini mendapatkan hasil bahwa iesain rumah makan berpengaruh terhadap kepuasan konsumen kedai Ohayo Kota Tarakan.

1. Inovasi berpengaruh terhadap kepuasan konsumen kedai Ohayo Kota Tarakan.

2. Desain rumah makan berpengaruh terhadap kepuasan konsumen kedai Ohayo Kota Tarakan

\section{$\underline{\text { Tinjauan Empiris }}$}

Salah satu data pendukung yang perlu dijadikan bagian tersendiri adalah penelitian terdahulu yang relevan dengan permasalahan dan metode yang sedang dibahas pada penelitian ini. Berikut merupakan penelitian terdahulu, berupa beberapa jurnal yang relevan dengan penelitian yang dilakukan:

1. Pengaruh Diferensial,variasi,dan inovasi Produk Terhadap Kepuasaan Konsumen (Memulai Keunggulan Bersaing Pada Produk Edamame PT.Mitratani 27) Berdasarkan penelitian Veri Agus Tomi (2014) menunjukan bahwa inovasi produk berpengaruh positif terhadap kepuasan konsumen, diterimanya hipotesis juga telah menunjukan pengaruh yang signifikan. Artinya semakin tinggi inovasi produk pada produk edamame pada PT. Mitratani 27 Jember juga mempengaruhi kepuasan konsumen.

2. Penelitian oleh Putu Sukarman, Andi Sularso, dan Deasy Wulandari (2013) dengan judul Analisis Pengaruh Inovasi Produk Terhadap Kepuasan Konsumen Dengan Keunggulan Bersaing Sebagai Variabel Intervening pada produk Gula Pasir Sebelas (GUPALAS) Pabrik Gula Semboro PTP Nusantara XI (PERSSERO) Menunjukkan bahwa inovasi produk berpengaruh positif terhadap Kepuasan Konsumen.

3. Penelitian Novarika Ariyanti,Stefanus Pani Rengu,Hermintatik (2015) dengan Judul Peran Desain Interior Terhadap Kepuasan Pemustaka (Studi pada Perpustakaan SMK Negeri 4 Malang) Menunjukkan bahwa 1) Elemen Desain interior yang meliputi tata ruang, tata warna, pencahayaan, sirkulasi udara (ventilasi) dan tata suara (akustik) secara bersama- sama berperan terhadap kepuasan pemustaka. 2) lima elemen desain interior (tata ruang,tata warna, pencahayaan, sirkulasi udara (ventilasi) dan tata suara(akustik)) pada perpustakaan SMK Negeri 4 Malang ada tiga elemen (pencahayaan, sirkulasi udara (ventilasi) dan tata suara(akustik)) yang berperan terhadap kepuasan pemustaka. 3) Elemen yang paling dominan mempengaruhi kepuasan pemustaka pada perpustakaan SMK Negeri 4 Malang adalah 
sirkulai udara (ventilasi). 4. Penelitian Timoticin Kwanda,Jani Rahardja,Bonivasius Risa Wibowo (2003) dengan judul Analisis Kepuasan Penghuni Rymah Sederhana Tipe 36 Di kawasan Sidoarjo berdasarkan faktor kualitas Banguna, Lokasi, Desain, Saran dan prasarana menunjukkan bahwa faktor kualitas Banguna, Lokasi, Desain, Saran dan prasarana memiliki pengaruh dan secara simultan berpengaruh terhadap kepuasan penghuni dengan uji $\mathrm{F}$.

\section{Definisi Konsep}

\section{Inovasi Produk}

Definisi mengenai pengertian inovasi produk menurut Kotler (2007) menyatakan bahwa inovasi produk adalah gabungan dari berbagai macam proses yang saling mempengaruhi antara yang satu dengan yang lain.

\section{Desain Rumah makan}

Desain rumah makan adalah Tema dan gaya desain sebuah restoran merupakan aspek pendukung yang mampu membedakan antara restoran satu dengan lainnya untuk menarik pengunjung (Lisa Sekar Sari 2014). Dalam Kamus Besar Bahasa Indonesia (2001), desain adalah kerangka bentuk suatu bangunan (rumah, taman, dan sebagainya), motif bangunan, pola bangunan dan corak bangunan. Desain interior merupakan kegiatan merencanakan, menata dan merancang ruang dalam bangunan. Penataan suatu ruang bertujuan agar pengguna merasa nyaman, betah dan senang merada di ruangan tersebut (Novarikha Ariyanti, 2014).

\section{$\underline{\text { Kepuasan Konsumen }}$}

Kotler dan Keller (2009), mengemukakan bahwa Kepuasan adalah perasaan senang atau kecewa seseorang yang muncul setelah membandingkan kinerja hasil produk yang dipikirkan terhadap kinerja atau hasil yang diharapkan. Jika kinerja berada di bawah harapan, pelanggan tidak puas. Dan jika kinerja memenuhi harapan, pelanggan puas. Jika kinerja melebihi harapan, pelanggan amat puas atau senang.Loyalitas Merek (Brand Loyalty)

$\underline{\text { Hipotesis }}$

Menurut Husein Umar (2008:8) Hipotesis adalah sebuah kesimpualan belum final, masih harus dibuktikan kebenarannya melalui penelitian. Dari pendapat ahli diatas dapat diartikan Hipotesis adalah dugaan sementara mengenai hubungan variabel yang kebenarannya masih harus dilakukan pengujian. Berdasarkan tinjauan diatas maka hipotesis yang akan diuji dalam penelitian adalah :

1. Hubugan antara Inovasi Produk terhadap Kepuasan Konsumen

Inovasi produk berpengaruh sisgnifikan terhadap kepuasan konsumen secara langsung (sutrasmawati,2008). Inovasi produk berpengaruh positif dan signifikan terhadap kepuasan konsumen (Tomi et al, 2014). Inovasi produk mempunyai pengaruh positif terhadap kepuasan konsumen 
(Natalia, 2009). Berdasarkan urain tersebut, maka dapat dirumuskan hipotesis sebagai berikut:

H1 : Inovasi produk berpengaruh terhadap kepuasan konsumen Kedai Ohayo Kota Tarakan

2. Hubungan Desain Rumah Makan terhadap Kepuasan Konsumen

Desain merupakan kegiatan merencanakan, menata dan merancang ruang dalam bangunan. Penataan suatu ruang bertujuan agar pengguna merasa nyaman, betah dan senang berada di ruangan tersebut (Ariyanti, 2014). Konsumen akan lebih banyak menghabiskan waktu dan uang di tempat yang lingkungan layanannya memberikan perasaan senang. Sehingga deangan desain rumah makan yang memiliki tampilan menarik menjadikan kepuasan bagi konsumen Yuksel dan Yuksel (2002). Desain interior secara bersama-sama berperan terhadap kepuasan pemustaka (Ariyanti, 2015). Desain interior dapat memberikan rasa nyaman akan mempengaruhi daya konsentrasi pemustaka (Wati, 2008). Desain bangunan mempuanyai pengaruh signifikan terhadap kepuasan penghuni perumahan (Kwanda, 2003) Berdasarkan uraian tersebut, maka dapat dirumuskan hipotesis sebagai berikut:

H2 : Desain Rumah Makan berpengaruh terhadap kepuasan konsumen Kedai Ohayo Kota Tarakan

\section{$\underline{\text { Kerangka Penelitian }}$}

Berdasarkan landasan teori, penelitian terdahulu dan tujuan penelitian maka kerangka pemikiran pengaruh inovasi produk,dan desain rumah makan terhadap kepuasan konsumen pada kedai Ohayo Kota Tarakan

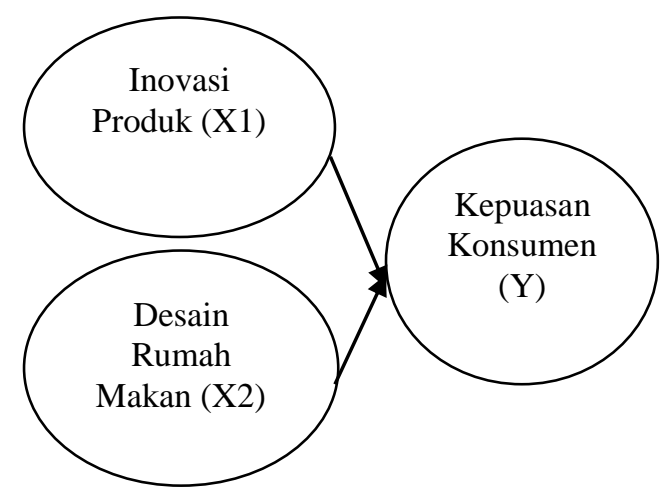

\section{METODOLOGI PENELITIAN}

Penelitian ini menggunakan pendekatan kuantitatif dengan metode survei. Teknik pengumpulan data yang digunakan adalah dengan menggunakan angket atau kuisioner. Populasi yang digunakan dalam penelitian ini adalah masayarakat Kota Tarakan Sampel adalah bagian dari populasi yang ingin diteliti. Penarikan sampel dalam penelitian ini menggunakan teknik non probability sampling dengan metode purposive sampling. Jumlah sampel ditentukan berdasarkan perhitungan dari rumus Hair et. al (2006) menyatakan bahwa untuk mengukur ukuran sampel dihitung antara (5-10) $\mathrm{x}$ jumlah indikator. Dari rumus tersebut, pengambilan sampel sebanyak $10 \times 19$ indikator $=190$ sampel. Jadi, sampel yang digunakan adalah sebanyak 190 Responden (orang yang akan menjawab). Skala pengukuran untuk semua indikator pada masing-masing variabel menggunakan skala Likert ( skala 1 sampai dengan 5) dimulai dari 
Sangat Tidak Setuju (STS) sampai dengan Sangat Setuju (SS). Skala pengukuran ini berarti bahwa jika nilainya semakin mendekati satu maka berarti semakin tidak setuju. Sampel yang digunakan harus dapat mewakili dan mencerminkan populasi yang ada. Sampel dalam penelitian ini adalah masyarakat Kota Tarakan dengan kriteria tertentu yaitu :

1. Responden yang meng konsumsi produk secara langsung di kedai ohayo Kota Tarakan

2. Responden telah melakukan pembelian produk pada kedai Ohayo dalam kurun waktu 6 bulan terakhir terhitung pada saat mengisis kuesioner

3. Responden telah melakukan pembelian produk pada kedai ohayo sebanyak 2 kali

4. Responden sudah pernah mengunjungi Rumah Makan lainnya .

Uji validitas digunakan untuk mengukur sah atau valid tidaknya suatu kuesioner (Ghozali, 2016). Suatu kuesioner dikatakan sah atau valid jika pertanyaan pada kuesioner tersebut mampu mengungkapkan sesuatu yang akan diukur oleh kuesioner tersebut. Uji signifikasi dilakukan dengan membandingkan nilai $r$ hitung dengan nilai $r$ tabel untuk degree of freedom (df) $=\mathrm{n}-2$ (n adalah jumlah sampel). Dengan jumlah sampel (n) adalah 190 dan tingkat signifikasi 0,05 . Jika $r$ hitung lebih besar daripada $r$ tabel dan nilai positif maka butir atau pertanyaan atau indikator tersebut valid.

Realibilitas adalah alat untuk mengukur suatu kuesioner yang merupakan indikator dari variabel atau konstruk. Suatu kuesioner dikatakan reliabel atau handal jika jawaban seseorang terhadap pernyataan adalah konsisten atau stabil dari waktu ke waktu (Ghozali, 2016). Suatu konstruk atau variabel dikatakan reliabel jika memberikan nilai Cronbach alpha $\geq 0,60$ (Ghozali, 2016)

Uji normalitas bertujuan untuk menguji apakah dalam model regresi, variabel pengganggu atau residual memilki distribusi normal. Seperti diketahui bahwa uji normalitas mengasumsikan bahwa nilai residual mengikuti distribusi normal. Untuk menguji apakah data berdistribusi normal atau tidak dilakukan uji statistik KolmogorovSmirnov Test. Residual berdistribusi normal jika memiliki nilai signifikansi > 0,05 (Ghozali, 2011). Nilai Asym. Sig. (2-tailed) dibandingkan dengan 0,05 (taraf signifikansi $5 \%$ sebesar $0,0751>$ 0,05 . Maka menunjukkan bahwa data terdistribusi normal.

Uji multikolonearitas bertujuan untuk menguji apakah model regresi ditemukan adanya korelasi antar variabel bebas (independen). Model regresi yang baik seharusnya tidak terjadi korelasi di antara variabel independen. Multikolonearitas dapat juga dilihat dari nilai tolerance dan variance inflation factor (VIF). Nilai cutoff yang umum dipakai untuk menunjukkan adanya multikolonearitas adalah nilai Tolerance $<0,10$ atau sama dengan nilai VIF >10 (Ghozali, 2016). Nilai Tolerance $>0,1$ dan VIF $<10$ sehingga dalam model regresi tidak terjadi multikolonieritas antara variabel bebas 
Uji heteroskedastisitas bertujuan menguji apakah dalam model regresi terjadi ketidaksamaan variance dari residual satu pengamatan ke pengamatan yang lain. Jika variance dari residual satu pengamatan ke pengamatan lain tidak tetap, maka diduga terdapat masalah heteroskedastisitas. Untuk mengetahui ada tidaknya heteroskedastisitas dalam penelitian ini digunakan scatter plot diagram. Jika data yang dimiliki terletak menyebar disekitar garis diagonal maka model regresi memenuhi normalitas dan tidak ada yang berpencar maka dapat dikatakan tidak terjadi heteroskedastisitas tetapi homoskedastisitas (Ghozali, 2016). Pada gambar grafik Scatterplot yang menunjukkan bahwa titik-titik menyebar secara acak serta tersebar diatas maupun dibawah angka 0 pada sumbu Y, serta tidak mempunyai pola yang jelas atau tidak membentuk suatu pola sehingga dapat disimpulkan bahwa tidak terjadi heteroskedastisitas pada model regresi, sehingga model regresi layak dipakai sebagai alat prediksi.

Uji autokorelasi bertujuan menguji apakah dalam model regresi linier ada korelasi antara kesalahan pengganggu pada periode $\mathrm{t}$ dengan kesalahan pengganggu pada periode t-1 (sebelumnya). Jika terjadi korelasi, maka dinamakan ada problem autokorelasi (Ghozali, 2016). Karena nilai $0<\mathrm{d}<\mathrm{dl}$ atau 0 $<1,282<1,7413$ disimpulkan bahwa tidak terdapat autokorelasi

Pengujian dengan analisis regresi

$$
\mathbf{Y}=\mathbf{a}+\boldsymbol{\beta} 1 \mathbf{X} 1+\boldsymbol{\beta} 2 \mathrm{X} 2+\mathbf{e}
$$

$$
\begin{aligned}
& \mathrm{Y}=\text { kepuasan konsumen } \\
& \text { a = Bilangan Konstanta } \\
& \beta 1 \mathrm{X} 1=\text { Koefisien Regresi } \\
& \text { Variabel inovasi produk } \\
& \beta 2 \mathrm{X} 2=\text { Koefisien Regresi Variabel } \\
& \text { desain rumah makan } \\
& \text { e } \quad=\text { Error term } \\
& \text { Uji } t \text { adalah pengujian }
\end{aligned}
$$

koefisien regresi parsial individual yang digunakan untuk mengetahui apakah variabel independen (X) secara individual mempengaruhi variabel dependen (Y) Cara 1 Jika Sig > 0,05 maka Ho diterima Jika Sig $<0,05$ maka Ho ditolak Cara 2 Jika $-\mathrm{t}$ tabel $<\mathrm{t}$ hitung $<\mathrm{t}$ tabel maka Ho diterima Jika $t$ hitung < -t tabel dan $\mathrm{t}$ hitung $>\mathrm{t}$ tabel maka Ho ditolak

\section{HASIL PENELITIAN}

\section{Hasil}

Uji hipotesis dalam analisis ini menggunakan SPSS versi 16.0 dengan melihat nilai $\beta$, serta membandingkan nilai $t$ hitung dengan $t$ tabel. Keputusan penerimaan hipotesis jika $\mathrm{t}$ hitung $>\mathrm{t}$ tabel, maka hipotesis diterima.

Tabel 1. Ringkasan Hasil Uji Hipotesis

\begin{tabular}{|l|c|c|c|c|}
\hline Hubungan & $\begin{array}{c}\text { t- } \\
\text { hitung }\end{array}$ & t-tabel & B & R2 \\
\hline Pengaruh & 2,064 & 1,981 & 0,183 & 0,172 \\
Inovasi & & & & \\
produk & & & & \\
terhadap & & & & \\
Kepuasan & & & & \\
Konsumen & & & 0,580 & \\
\cline { 1 - 2 } $\begin{array}{l}\text { Pengaruh } \\
\text { desain }\end{array}$ & 3,808 & & & \\
rumah & & & & \\
makan & & & & \\
terhadap & & & & \\
kepuasan & & & & \\
konsumen & & & & \\
\hline
\end{tabular}

Keterangan : 
Hipotesis 1 : Inovasi produk berpengaruh terhadap kepuasan konsumen

Ringkasan hasil uji hipotesis pertama menunjukkan bahwa hubungan tersebut memiliki nilai thitung sebesar 2,064 signifikan pada $\alpha=0,05$ (two tailed) nilai ttabel 1,981 , maka dari itu nilai thitung > ttabel dan nilai signifikan $<0,05$. Hal tersebut menunjukkan bahwa inovasi produk berpengaruh positif signifikan terhadap kepuasan konsumen. Dengan demikian dapat disimpulkan bahwa hipotesis 1 diterima. Hasil penelitian ini sesuai dengan penelitian yang dilakukan oleh veri agus tomi (2014) putu sukarmen (2013)

Hipotesis 2 : Desain rumah makan berpengaruh terhaadap Kepuasan Konsumen

Pada tabel Ringkasan hasil uji hipotesis kedua menunjukkan bahwa hubungan tersebut memiliki nilai thitung 3,808 dan ttabel 1,981, maka dari itu nilai thitung $>$ ttabel dan nilai signifikan $<0,05$. Dengan demikian dapat disimpulkan bahwa hipotesis 2 diterima. Hasil penelitian ini sesuai dengan penelitian yang dilakukan oleh timotici kwanda (2003) novarika (2015).

\section{$\underline{\text { Pembahasan }}$}

Inovasi Produk Berpengaruh Terhadap Kepuasan Konsumen

\begin{tabular}{lrr}
\multicolumn{2}{c}{ Berdasarankan } & hasil \\
penelitian yang dilakukan & pada \\
konsumen & Kedai & Ohayo
\end{tabular} menunjukkan bahwa inovasi produk berpengaruh positif signifikan terhadap kepuasan konsumen pada Kedai Ohayo Kota Tarakan. Artinya, bahwa semakin tinggi Inovasi Produk, maka semakin tinggi kepuasan konsumen. Hal ini dibuktikan dengan kriteria responden dimana responden mengetahui inovasi produk yang dilakukan perusahaan sejenis. Artinya responden dapat membandingkaan inovasi yang dilakukan kedai ohayo dengan rumah makan yang sejenisnya penelitian ini sesuai dengan penelitian yang dilakukan oleh Putu Sukarmen (2013) bahwa inovasi produk berpengaruh signifikan terhadap kepuasan konsumen artinya semakin tinggi inovasi produk semakin tinggi kepuasan konsumen. Inovasi produk berpengaruh positif dan signifikan terhadap kepuasan konsumen (Tomi et al, 2014) artinya semakin tinggi inovasi produk juga akan mempengruhi kepuasan konsumen. Inovasi produk mempunyai pengaruh positif terhadap kepuasan konsumen (Natalia, 2009).

Desain Rumah Makan Berpengaruh Terhadap Kepuasan Konsumen

Konsumen akan lebih banyak menghabiskan waktu dan uang di tempat yang lingkungan layanannya memberikan perasaan senang. Sehingga dengan desain rumah makan yang memiliki tampilan menarik menjadikan kepuasan bagi konsumen. Berdasarkan hasil penelitan yang dilakukan pada konsumen Kedai Ohayo menunjukkan bahwa desain rumah makan berpengaruh positif signifikan terhadap kepuasan konsumen pada Kedai Ohayo Kota Tarakan. Artinya, bahwa semakin tinggi desain rumah makan, maka semakin tinggi 
kepuasan konsumen Hal ini dibuktikan pada indikator desain rumah makan yang menyatakan bahwa jawaban responden menunjukkan hal yang terpenting pada desain rumah makan adalah faktor lingkungan, gaya arsitektur, tata letak rumah makan, perabot dan material, faktor-faktor sosial, serts faktor susasana. Artinya penciptaan suasana nyaman yang didukung dengan desain interior unik dan tersedianya berbagai fasilitas tambahan seperti hiburan dan wifi yang merupakan daya tarik khusus bagi para konsuen kedai Ohayo. Sejalan dengan penelitian (Ariyanti, 2015) Desain interior secara bersamasama berperan terhadap kepuasan pemustaka dan. Desain bangunan mempuanyai pengaruh signifikan terhadap kepuasan penghuni perumahan (Kwanda, 2003).

\section{KESIMPULAN}

Berdasarkan hasil penelitian dan pembahasan hasil pengujian hipotesis atas pertanyaan-pertanyaan penelitian maka dapat diambil kesimpulan sebagai berikut :

1. Inovasi Produk berpengaruh positif dan signifikan terhadap Kepuasan Konsumen pada Kedai Ohayo Kota Tarakan. Artinya bahwa semakin tinggi inovasi produk, maka semakin tinggi pula Kepuasan konsumen terhadap produk Kedai Ohayo kota Tarakan.

2. Desain Rumah Makan berpengruh positif dan signifikan terhadap Kepuasan Konsumen. Artinya semakin tinggi desain rumah makan, maka semakin tinggi kepuasan konsumen pada kedai Ohayo kota Tarakan.

\section{SARAN}

Berdasarkan dari kesimpulan penelitian ini, maka dapat dikemukakan saran-saran sebagai berikut :

1. Bagi pemasar kepuasan konsumen secara signifikan dipengaruhi oleh inovasi produk dan desain rumah makan. Berdasarkan hal tersebut maka penting bagi pemasar untuk memperhatikan faktor - faktor yang mempengaruhi inovasi produk dan desain rumah makan dalam menikmati produk pada kedai Ohayo kota Tarakan sehingga kedai Ohayo dapat menjadi tempat pilihan oleh konsumen untuk memenuhi kebutuhannya. Hal itu dapat terjadi jika pemasar mempertahankan produk dan mengembangkan kearah yang lebih baik agar dapat meningkatkan volume penjualan produk Kedai Ohayo.

2. Bagi peneliti Dalam penelitian ini menggunakan metode nonprobability sampling dengan teknik pengambilan sampel

\section{DAFTAR PUSTAKA}

Ariyanti, Novarikha, Stefanus Pani Rengu, Hermintatik. Peran Desain Interior Terhadap Kepuasan Pemustaka (Studi pada Perpustakaan SMK Negeri 4 Malang). Jurnal Administrasi Publik (JAP), 
Vol. 3, No. 11, Hal. 18681873

Charles W. Lamb, Joseph F. Hair, Carl Mcdaniel. 2001 Pemasaran. Edisi pertama, Salemba Empat. Jakarta

Charles, Noble H.; Sinha, Rajiv K. and Kumar, Ajith. 2002., Market Orientation and Alternative Strategic Orientations : A Longitudinal Assessment of Performance Implications, Journal of Marketing vol. 66, 25-39

David, Fred, R. 2011. Strategic Management Manajemen Strategi Konsep. Edisi 12. Salemba Empat. Jakarta

Farelly, Lorraine. (2003). Bar and Restaurant Interior Structures Chichester : Jhon Willery \& Sons Ltd.

Gatignon, Hubert \& Jean Marc Xuerob. (1997). "Strategic Orientation of The Firm and new Product

Performance".

Journal of Marketing Research. p.77-79.

Griffin. Ricky W. 2004. Manajemen. Edisi Kesepuluh. Jakarta. Erlangga.

Hair, et al. 2006 : Multivariate Data Analysis, Sixth edition , Pearson Prenice Hall. New Jersey

Han, Jin K, Narwoon Kim \& Srivastava, Rajendra K. (1998). "Market Orientation an
Organization

Performance: Is Innovation Missing Link?". Journal of Marketing. P.42-54.

Hasibuan, Malayu. 2007. Manajemen Sumber Daya Manusia. Jakarta: Cetakan 9. PT. Bumi Aksara

Hatane Semuel, Hellen Novia, Annette V. Kosasih. 2007. "Perilaku dan Keputusan Pembelian Konsumen Restoran Melalui Stimulus 50\% Discount di Surabaya”. Jurnal Manajemen

Pemasaran, Vol.2, Oktober, h. 73-80.

Hurley, Robert. F and Hult, G, Tomas. M, 1998, "Inovation, Market Orientation, and Organizational Learning: $\quad A n$ Intergration and Empirical Examination", Journal of Marketing, July. 